\title{
Practice as a component of professional training of the elementary school teachers
}

\author{
Tatyana Ulyanitskaya ${ }^{1, *}$ \\ ${ }^{1}$ Kazan (Privolzhsky) Federal University, 420008, 18 Kremlyovskaya str., Kazan, Russia
}

\begin{abstract}
In this article, the author considers practical training as an independent component of the general system of vocational training for future teachers, as well as goals and objectives, the structure, content, and organization of the practice of future primary school teachers and English speakers.
\end{abstract}

In a rapidly changing open world, the main professional quality, which should be constantly demonstrated by a teacher to his/her students, is the ability to learn. Readiness for change, mobility, the ability for non-standard labor actions, responsibility, and independence in decision-making, - all these characteristics of a successful professional fully apply to the teacher [1]. Therefore, the search for ways, the development of educational technologies in higher education, which would be aimed at the formation of the psychological, pedagogical, special, and methodological knowledge, skills, as well as general, cultural, and professional competencies of the future teachers, along with stimulating their self-development, is so relevant today. Important is also the development of the motivational sphere and the professional-pedagogical orientation of the students' personality. In this regard, at present, the professional preparation of future teachers is the subject of many scientific studies.

In contemporary Social Sciences, there are various definitions of the concept of "vocational training," and for future teachers particularly. For example, Ippolitova considers professional training of students of a pedagogical university as an integral pedagogical system whose functioning presupposes creating conditions for the development of the future teachers' personality on the basis of mastering their knowledge and skills necessary for pedagogical activity, developing significant qualities professionally and personally that ensure the effectiveness of pedagogical activity [2].

In her work, Ippolitova defines practical training in a relatively independent component of the general system of vocational training for future teachers. This involves mastering students' skills in the field of pedagogical technology, as well as ways and methods of organizing pedagogical interaction with pupils in the process of solving pedagogical problems.

In the study of Kryuchkova, structural components of the process of vocational training of future teachers of primary classes are considered: motivational, informative, organizational-methodical, evaluative-productive.

\footnotetext{
* Corresponding author: ultv71@ mail.ru
} 
To the motivational block of a student training system, Kryuchkova refers to the system of external and internal motives (needs, aspirations, ideals), the totality of all psychological moments. The content component of preparing a future primary school teacher, according to the scholar, includes the following types of training: methodological, theoretical, technological, and methodical, which, while being interrelated, ensure the effectiveness of the standard in primary school [3].

Practice occupies one of the central places in the professional training of teachers. It is the foundation for the formation and development of general cultural and professional competencies of future teachers and the stimulation of their self-development. It is in practice where a student can determine how correctly he/she choses the scope of activity, as well as the degree of correspondence of those personal qualities and individual characteristics that are professionally significant for a teacher. Practice helps to form a methodical reflection in the conditions of a natural pedagogical process. An analysis of one's own activity helps a trainee to realize the difficulties that arise in his/her work and to find competent ways to overcome them.

From the point of view of the temporary organization model, there are continuous practical training and intensive discrete practical training [4].

Continuous practical training of teachers provides for gradual mastering by students of the skills from the main functional areas of pedagogical activity, starting with those that do not require fundamental training in the subject of teaching and can be implemented in junior courses: organizational, communicative, didactic, diagnostic, and other skills being implemented during extracurricular activities in the school and in the work of a summer health camp. After that, on the basis of such fixed skills, a set of didactic skills is developed to implement the function of a teacher.

Intensive-discrete practical training of teachers provides for a one-time "immersion" of undergraduate students in the practical work of a school teacher with the fulfillment of all functional duties with a high level of independence and with almost complete theoretical preparation. Such an organization model assumes a one-time parallel development of all skills [4].

When planning and organizing the practice of students of future primary school teachers, we are guided by the following main normative documents:

1) the federal state educational standard of higher education;

2) the professional standard "Teacher (pedagogical activity in the field of preschool, primary general, basic general, secondary general education)";

3) the federal state educational standard of primary general education;

4) the main educational programs and curricula.

According to the Federal State Educational Standard of Higher Education in the field of training "44.03.05 Pedagogical education" (with two profiles) a bachelor's program consists of the following units:

1) Block 1: "Disciplines (modules)."

2) Block 2: "Practice."

3) Block 3: "State final attestation."

The Block 2 of "Practice" focuses on training and production, including pre-diploma practice. Types of training practice include the practice of obtaining primary professional skills. Methods of conducting the practice: stationary, exit. Types of industrial practice: pedagogical; cultural and educational, summer pedagogical. Pre-diploma practice is conducted for the performance of final qualification work and is mandatory [5].

According to the curriculum in the field of training "44.03.05 Pedagogical education :(with two profiles), the profile "Primary education and foreign (English) language" provides a number of types of practices, all of which are reviewed below. 


\section{Educational (dispersed), 1st course, 2nd semester}

The purpose of the training practice at the first course is to familiarize students with the basics of their future professional activity of primary school teachers and to master the primary professional skills.

The main objectives of the training practice are:

- Formation of interest in the future profession, professionally significant personal qualities of students as the future teachers of primary school;

- Formation of the ability to outline the course of a lesson, highlighting its main stages and timing;

- Formation of the ability to analyze lessons of the basic school subjects in the elementary school (mathematics, Russian language, literary reading, the world around) in terms of rational organization and planned results;

- Formation of general cultural and professional competencies of students;

- Formation of communicative abilities of students.

The training practice in the first year is distributed. In the calendar training schedule, the period of practice is combined with theoretical studies. During the practice, students attend lessons of experienced primary school teachers of basic schools, record observations, and analyze lessons on certain schemes.

\section{Practice (dispersed), 2nd-3rd courses, 3rd and 5th semesters}

The goal of the professional (psychological and pedagogical) practice of students for the future primary school teachers is the formation of personal and professional readiness for the implementation of basic types of professional activity.

The tasks of professional (psychological-pedagogical) practice are:

- Development of professionally significant personal qualities and pedagogical abilities in the future teachers of primary classes;

- Formation of the skills of studying and analyzing the current state of teaching and upbringing work in the primary school, obtaining an advanced pedagogical experience;

- Formation of general, cultural, and professional competencies of students;

- Formation of skills to apply theoretical positions on the subjects of the psychological and pedagogical cycle in solving pedagogical problems;

- Formation of skills to plan, organize, and conduct educational activities in primary school;

- Fulfillment of assignments for the academic disciplines of the psychological and pedagogical cycle.

The period of conducting psychological and pedagogical practice in the educational schedule is combined with theoretical studies. During the practice, students attend lessons of experienced primary school teachers of basic schools, carry out assignments in psychology and pedagogy, and conduct educational activities in primary school.

\section{Training practice (preparation for a camp), 2nd year, 4th semester}

The purpose of the training practice is to form students' readiness to organize educational work with children of primary school age in school camps and summer health camps.

The objectives of the training practice:

- Familiarization of students with modern experience in organization of rest and education of junior schoolchildren in the school camp of general schools and children's health camp; 
- Familiarization of students with certain specifics of working as counselors in school camps and children's health camps and with normative documents that ensure the work of the camp;

- Formation of students' psychological knowledge in the field of organizing and rallying temporary children's collective groups;

- Formation of students' knowledge of the methods of educational work with junior schoolchildren in the conditions of a school camp and a children's health camp.

\section{Professional (summer/teaching) practice, 2nd year, 4th semester}

The goal of the professional (summer/pedagogical) practice is the formation of students' readiness for organizing and conducting educational work with children of primary school age in school camps and summer health camps:

- Familiarization of students with modern experience in organization of rest and education of junior schoolchildren in school camps of general schools and children's recreation camps;

- Formation of students' knowledge of the methods of educational work with junior schoolchildren in conditions of a school camp or a children's health camp;

- Formation of students' skills in planning, organizing, and conducting educational activities with junior schoolchildren in the conditions of a school camp and a children's health camp.

Summer pedagogical practices of students are held in school camps of secondary schools/gymnasiums or in children's health camps (as an assistant counselor). Students can work during this period as counselors in children's health camps.

\section{Professional practice (4th year, 7th semester)}

The purpose of the practice is to deepen the theoretical knowledge of students in Pedagogy, Psychology, and the discipline "Theory and methodology of teaching the subject" (especially, the blocks on developing general cultural and professional competencies, preparing for independent professional and pedagogical activities as a teacher of primary classes in general education institutions 0 .

Objectives of the professional practice:

- consolidation and deepening in students of psychological, pedagogical, and special (in terms of subjects) knowledge and their application in teaching and educational work with children of primary school age;

- Development of students' skills in planning, organizing, and analyzing educational work with children, taking into account their individual characteristics, taking care of the health of junior schoolchildren in the conditions of general educational institutions;

- Preparation of students for performing functional duties of a primary school teacher and a class teacher in an elementary school;

- Formation of students' skills of analysis and generalization of advanced pedagogical experiences, its use in independent pedagogical activity;

- Development of professionally significant qualities of the personality of future teachers of primary classes, as well as the need for professional self-development;

- Education of a sustainable interest in the profession of the teacher.

The content of the professional practice for the 4th year includes:

- Study, analysis, and testing in practice of the methods and means within the framework of educational technology, which is realized in the class; 
- Observation, summary, and analysis of lessons, extra-curricular activities conducted by the teacher and other students;

- Attending a parent meeting;

- Development of abstracts and conducting trial lessons in the Russian language, literary reading, mathematics and a test lesson in the surrounding world in the primary school.

\section{Educational Practice (first days of a child in school), 5th year, 9th semester}

The purpose of the training practice of students, future primary school teachers, is the formation of personal and professional readiness for the implementation of basic types of professional activity.

The objectives of the training practice are:

- Familiarization of students with certain peculiarities of the educational process in the first days of the child's schooling;

- Familiarization of students with the peculiarities of the teacher's work with first-graders and their parents in the first week of the school year;

- Formation of students' research skills related to the identification of the level of preparedness of children for schooling;

- Disclosure of continuity in work with children of pre-school institutions, families, and schools.

The content of the practice includes acquaintance with the organization of the educational process in the school at the beginning of the academic year; analysis of activities related to the Day of Knowledge; meetings with first-graders; assistance to a teacher in the preparation of training sessions, etc.

\section{Professional (pedagogical) practice (5th year, 9th semester)}

The purpose of the practice is to deepen the theoretical knowledge of students in foreign (English) language, develop cultural and professional competencies, get prepared for independent professional and pedagogical activities as an English teacher in the general education school.

\section{Professional (pedagogical) practice (5th year, 10th semester)}

Preparation for independent professional and pedagogical activity as a teacher of primary classes in general education institutions includes a number of steps.

Objectives of any professional practice:

- Consolidation and deepening in students of psychological, pedagogical, and special (in terms of subjects) knowledge and their application in teaching and educational work with children of primary school age;

- Development of students' skills in planning, organizing, and analyzing educational work with children, taking into account their individual characteristics, taking care of the health of junior schoolchildren in the conditions of general educational institutions;

- Preparation of students for the performance of the functional duties of a primary school teacher and a class teacher in an elementary school;

- Formation of students' skills of analysis and generalization of advanced pedagogical experience, its use in independent pedagogical activity;

- Development of professionally significant qualities of the personality of the future teacher of primary classes, the need for professional self-development;

- Education of a sustainable interest in the profession of the teacher. 
The content of the professional practice includes:

- Study and analysis of normative and legal documents characterizing the content of primary general education (the Federal State Standard of Primary General Education, working programs of educational disciplines, methodological aids, textbooks, etc.);

- Study of the rules for conducting school records (class journal, electronic journal, personal files of students, plans for educational work, work curricula in subjects, thematic plans, lessons, etc.);

- Observation, summary, and analysis of the lessons of the Russian language, literary reading, mathematics, the surrounding world, technology of various types, which are conducted by the teacher;

- Development of lessons' summaries (in the Russian language, mathematics, literary reading) under the guidance of a methodologist and a teacher-teacher;

- Conducting trial lessons and test lessons for each of the subjects;

- Developing a summary and conducting a trial and test after-school cognitive activity;

- Organizing and conducting the ascertaining and forming stages of a pedagogical experiment (with the planned experimental work) or studying the experience of the primary school teacher in the framework of final qualification work.

\section{Pre-diploma practice (5th year, 10th semester)}

The main goal of the pre-diploma practice focuses on completing the final qualification work, organizing and conducting the pilot phase of an experiment.

When organizing and conducting all types of practice of students, the future teachers of primary classes should focus on:

- Stimulating students' activities, which involves using forms, methods, and means of teaching that enhance students' interest, creativity in mastering new knowledge, developing skills, applying them in practice, and also focusing on professional self-development;

- Taking into account theoretical foundations of professional and pedagogical activity and, consequently, the consistency of the tasks and content of the stages of passing the practice with the subjects;

- Collective and group ways of teaching are to be implemented in the course of practicing group creative assignments, projects;

- Teaching the team;

- Attending and analyzing lessons and extra-curricular activities by a group being led by a methodologist;

- Conducting master classes on practical methodology in general schools;

- Taking into account professional interests and wishes of students in the course of pedagogical practice;

- At the end of each type of practice, students submit a report on the passage of training or production practices numbers.

\section{References}

1. Rossiyskaya Gazeta, The Standard "Teacher" (https://rg.ru/2013/12/18/pedagogdok.html, 2013)

2. N. V. Ippolitova, Developing the personality of a future teacher in the context of vocational training (ShGPI, Shadrinsk, 2010)

3. T. A. Kryuchkova, Bulletin of the Shadrinsky State Pedagogical University, 3 (2010)

4. V. I. Blinov, Pedagogical Sciences and Practice: Problems and Perspectives, 2 (2004) 
5. Federal State Educational Standard of Higher Education in the Field of Training 44.03.05 Pedagogical Education (Bachelor's Degree) (http://fgosvo.ru/news/7/1805, 2014) 